the work of the commissions. The formation of such commissions would be a great step forward in promoting the international recognition of trusteeship, as opposed to ownership, of Colonial territories.

\section{Aspects of Demobilization}

THE jmportant address of Sir William Jowitt to representatives of municipal and business interests of Merseyside, delivered in Liverpool on June 17, directed attention to a vital but complex aspect of post-war reconstruction. The complexity of the problems of demobilization should be apparent to all, but Sir William Jowitt's remarks on the subject were reassuring in that he said that the fatal mistakes of 1918-19 will not be repeated. Sir William urged that it would be foolish to involve members of the Fighting Forces in any controversy about rival schemes of demobilization ; past experience justifies the reminder that it would be highly dangerous. The very difficulty of devising a fair and efficient scheme of demobilizing in the shortest possible time a huge number of men and wcmen and resettling them in peace-time work in industries, most of which would be short of raw materials, while many of the factories would require re-tooling and re-arranging, makes it imperative that a policy should be decided upon promptly and that it should be explained intelligently as soon as possible to prevent misunderstanding later on. Sir William Jowitt stated that the Government has adopted a scheme in which the guiding factors are age and length of service. Clearly, however, demobilization cannot be based entirely on these principles. The necessity for armies of occupation, apart from the probability of the war with Japan continuing after Germany has been defeated, will involve a partial demobilization, and the release of men may have to be determined to some extent on transport grounds, for example. Similar considerations may apply to industry. A more orderly transition from war to peace than in 1918 means that some workers will be more urgently required than others when peace. time industry is starting up and the process of reequipment and reconstruction commences.

The Economist has indicated some broad principles of industrial demobilization that merit consideration. Capacity capable of working directly for export should be freed from war obligations as soon as possible. Food, clothing and shelter should come before luxuries. Industries capable of being reconverted to peace work without expensive re-equipment and re-tooling should be allowed to turn over as soon as practicable, to economize the resources needed for immediate reconstruction. British demobilization, both of machines and men, should be an integrated part, not only of the continuing war effort of the United Nations, but also of the joint plans made by them for relief and reconstruction on a world scale. The service of such principles leaves no room for pointless argument, but equally it demands of the Government prompt decisions which must be made known and fully explained. In demobilization-and indeed in reconstruction generally-the channels of assent can never be dug too deep if acrimony is to be avoided.

\section{Association of Teachers in Technical Institutions}

AT the annual conference of the Association of Teachers in Technical Institutions, held in London during Whitsuntide, Mr. J. C. Hazelip of the Leeds College of Commerce was inducted as president of the Association. It is some fifteen years since a teacher of commerce was elected to the office. In his presidential address Mr. Hazelip referred to the additional work undertaken by technical colleges during the War. It includes training of R.A.F. and Royal Navy personnel in radio work and of the R.A.O.C. and the R.E.M.E. for the many maintenance jobs which a mechanical army needs in the field. There is also the training of members of the A.T.S. for clerical and other work. Mr. Hazelip stressed the importance of this contribution by the technical colleges to the national war effort "since success in modern warfare is largely a matter of being in possession of the necessary equipment and of the technical skill to keep it in working order". Thus, he said, the work of technical education is an important factor in bringing the present struggle to a successful issue. He.stressed. too, the fact that this additional work had gone on "without interference with normal technical college activities". With the possibilities of an Education Bill in mind Mr. Hazelip sketched arguments against merging junior technical and commercial schools into a "multilateral school". Technical education, he said, must be conducted in an atmosphere of realism and must be able to call upon the services of men and women who themselves had experienced the difficulties and problems "inherent in the spheres for which the students are being prepared educationally". Technical education must be dovetailed into the industrial and commercial life of the community round it. This realistic atmosphere, he said, could not be found in the normal secondary school. He insisted, however, that notwithstanding the realism of its approach, the junior technical school in its work in English subjects, science and foreign languages, would stand comparison with any similar work now being carried on in any other type of post-primary school.

\section{War Background Studies}

No. 7 of the series of Smithsonian Institution War Background Studies, by J. F. Embree, is devoted to an account of the Japanese nation, its origins and present social structure. The reader is assumed to have some familiarity with Japanese art and litera. ture, costume and types of building. The economic framework of the lives of the people is only very briefly touched upon, and nothing is said about the physical geography or climatic conditions of the country. On the other hand, nearly half of the 36 pages are devoted to the family and household structure and to the customs surrounding the events of the individual life from birth to death, and there is a short chapter on religious beliefs. The author is of the opinion that the obvious differences between the mental processes of adult Japanese and Americans are solely the result of these customs, outlook, and beliefs. Perhaps the most helpful and charming feature of this brochure is its sixteen excellent photographic plates.

No. '8 of these Smithsonian pamphlets, by H. G. Deignan, gives an account of Siam and its inhabitants. In this case a description of the geographical setting is given, and the whole work might be considered as an introduction, but little more, to what would indeed prove a very interesting study. The region dealt with can be divided into a northern, an eastern and a central area, the latter passing down south. wards into the Malay peninsula to the frontier of the Straits Settlements. The aboriginal Negrito popula. 